\title{
Germination and Vigor of Black Bean (Phaseolus vulgaris L.) Cultivars Subjected to Saline Stress Conditions
}

\author{
Lucas Vinícius de Souza Cangussu', Andréia Márcia Santos de Souza David², \\ Fernando Henrique Batista Machado ${ }^{2}$, Josiane Cantuária Figueiredo ${ }^{3}$, Cleisson Dener da Silva ${ }^{2}$, \\ Rayane Aguiar Alves ${ }^{4}$, Jorge Luiz Rodrigues Barbosa ${ }^{3}$, Kennia Karolline Gonçalves Pereira ${ }^{2}$, \\ Ruthelly Viereca Sena Rocha ${ }^{2}$, Eliene Almeida Paraizo ${ }^{2}$, Edileuza dos Reis Souza Conceição ${ }^{2}$, \\ \& Danúbia Aparecida Costa Nobre ${ }^{1}$ \\ ${ }^{1}$ Universidade Federal Vales do Jequitinhonha e Mucuri, Diamantina, Minas Gerais, Brazil \\ ${ }^{2}$ Universidade Estadual de Montes Claros, Janaúba, Minas Gerais, Brazil \\ ${ }^{3}$ Universidade Federal de Pelotas, Capão do Leão, Rio Grande do Sul, Brazil \\ ${ }^{4}$ Universidade Federal de Minas Gerais, Montes Claros, Minas Gerais, Brazil \\ Correspondence: Josiane Cantuária Figueiredo, Universidade Federal de Pelotas, Capão do Leão, Rio Grande do \\ Sul, Brazil. E-mail: josycantuaria@yahoo.com.br
}

Received: December 15, 2019

Accepted: July 8, $2020 \quad$ Online Published: August 15, 2020

doi:10.5539/jas.v12n9p159

URL: https://doi.org/10.5539/jas.v12n9p159

\begin{abstract}
Natural factors such as salinity act directly on seed germination and vigor and, consequently, affect the establishment and development of seedlings in the field. In view of the above, the objective of this study was to assess the effect of saline stress on the germination and vigor of seeds from black bean cultivars. The study was conducted at the Seed Analysis Laboratory of the State University of Montes Claros, Janaúba-Minas Gerais, Brazil. The experimental design was completely randomized, in a $2 \times 5$ factorial arrangement (two cultivars $\times$ five osmotic potentials), with four repeats of 50 seeds per treatment. Bean seeds from cultivars Campeiro and Esteio were used, with sowing carried out on germitest paper rolls moistened at five osmotic potentials via sodium chloride solutions $(\mathrm{NaCl})$ : 0.0 [distilled water]; $-0.3 ;-0.6 ;-0.9$ and $-1.2 \mathrm{MPa}$. Seed rolls were kept in a digital germinator, and the germination and vigor percentages of the seeds were determined by first germination count, germination speed index (GSI), and fresh and dry mass of seedlings. The germination and vigor of seeds from common-bean cultivars, black commercial type, are negatively affected under saline stress caused by $\mathrm{NaCl}$ solution with osmotic potential lower than -0.6 MPa. The seeds of the studied cultivars showed a different behavior regarding saline stress conditions, and cultivar Campeiro proved to be more tolerant to saline stress in relation to Esteio during the germination process and seedling formation.
\end{abstract}

Keywords: sodium chloride, Phaseolus vulgaris L., osmotic potential, salinity, viability

\section{Introduction}

Germination tests run in laboratory aim to qualify and quantify the number of living seeds capable of producing normal plants under favorable field conditions (Figliolia et al., 1993). In addition to germination, there are vigor tests, which better predict performance in the field and allow for understanding the actual sowing (Wendt et al., 2017). According to the same author, a simple study relating vigor tests to seedling establishment in the field is usually adopted to ratify the behavior of the potential quantified in laboratory.

Verifying the germination capacity and vigor of a seed batch is fundamental for crop establishment, since both processes can be influenced by natural factors, as it is the case of salinity, which, in excess, can impair plant development. This abiotic factor present in arid and semi-arid regions is a limiting factor for agricultural production (Santos et al., 2009).

The negative effect of excessive salinity is due to both osmotic effect and toxic effect (Monterle et al., 2006), which cause reductions in emergence speed, uniformity, initial size and stand establishment, factors that can have an influence on dry matter accumulation and, consequently, affect crop productivity (Scheeren et al., 2010). 
An alternative to overcome this unfavorable condition, especially in early stages of development, is the selection of tolerating cultivars, which allows for obtaining a more vigorous plant stand, thus ensuring a successful crop implantation.

For bean seeds (Phaseolus vulgaris L.), it is of paramount importance to conduct researches that indicate the best germination and early development conditions of seedlings under saline stress, as well as the most indicated genotypes, since saline stress can hinder water absorption or make this process irreversible. In light of the foregoing, the objective of the present study was to assess the effect of saline stress on germination and vigor of black bean seeds.

\section{Material and Methods}

The investigation was conducted at the Seed Analysis Laboratory of the Department of Agrarian Sciences, State University of Montes Claros-UNIMONTES, Janaúba-Minas Gerais, Brazil. It used seeds of commercial black beans produced at Unimontes' Experimental Farm, Janaúba-MG, 2017 harvest.

The region's climate, as per Koppen classification, is "AW" type - tropical with dry winter. The region's climatic conditions are represented by average temperatures ranging from 21 to $25^{\circ} \mathrm{C}$, daily relative humidity of 60 to $70 \%$, and average annual rainfall of approximately $900 \mathrm{~mm}$.

The experimental design adopted was completely randomized, in a $2 \times 5$ factorial arrangement (two cultivars $\times$ five osmotic potentials), with four repeats of 50 seeds per treatment. The two black bean cultivars (Campeiro and Esteio) and the five osmotic potential levels (0.0 [distilled water];-0.3; $-0.6 ;-0.9$ and $-1.2 \mathrm{MPad}$ ] were sourced from aqueous sodium chloride $(\mathrm{NaCl})$ solutions, prepared according to specifications by Vilela et al. (1991).

For the germination test, the seeds were sown on germitest ${ }^{\circledR}$ paper moistened with the formulated $\mathrm{NaCl}$ solutions, in an amount equivalent to 2.5 times the weight of the dry paper, in order to provide the osmotic potentials previously described. Afterwards, rolls were made and placed in digital germinator regulated in advance at a constant temperature of $25{ }^{\circ} \mathrm{C}$. Assessments were carried out on the fifth and ninth days after sowing, and results were expressed as percentages of normal seedlings, in accordance with the Seed Analysis Rules (Brasil, 2009).

The first-germination-count test was run together with the germination test, which provided the number of normal seedlings, determined on the occasion of the fifth-day count after test assembling, with results being expressed as percentages (Brasil, 2009). Along with this, the germination speed index (GSI) was verified, when the number of germinated seeds was daily registered, and, at the end of the test, the GSI was calculated according to formula proposed by Maguire (1962).

Normal seedlings resulting from the germination test were weighed on a 0.0001 precision scale for dry matter weight. Later, the seedlings were placed in paper bags and taken to dry in a forced air circulation oven at $65{ }^{\circ} \mathrm{C}$ for 72 hours. After this period, the samples were left cooling in dissectors and then again weighed on precision scale for dry matter weight determination. Results were expressed as $\mathrm{g}$ repeat ${ }^{-1}$.

Data were subjected to analysis of variance, at a 5\% level of probability, and subsequent regression analysis. When significant, the effects of cultivars were studied by Tukey's test at a 5\% significance, while the effects of osmotic potentials were studied by regression analysis, choosing the adequate models to represent them as a function of their biological behavior, of the significance of the coefficients and of the determination coefficient value $\left(\mathrm{R}^{2}\right)$.

\section{Results and Discussion}

The results of the analysis of variance revealed that only variables 'germination' and 'germination speed index' (GSI) were influenced by the interaction between factors 'cultivars' $\times$ 'osmotic potentials'. There was significant effect as to isolated factors for first germination count, fresh mass and dry mass of seedlings.

For both cultivars, germination results (Figure 1A) fit into a regression equation of linear descending behavior. As the osmotic potential of the solution reduced, meaning higher $\mathrm{NaCl}$ amount and lower water availability, there were proportional decreases in the germination of the bean seeds for both cultivars, although cultivar Esteio has presented higher sensitivity for all potentials (Figure 1A). 
-... Campeiro $\hat{Y}=111.5500-21.8500 \times R^{2}: 87.07 \%$ Esteio $\hat{Y}=105.9000 \cdot 22.4000 \mathrm{x} R^{2}: 95.50 \%$

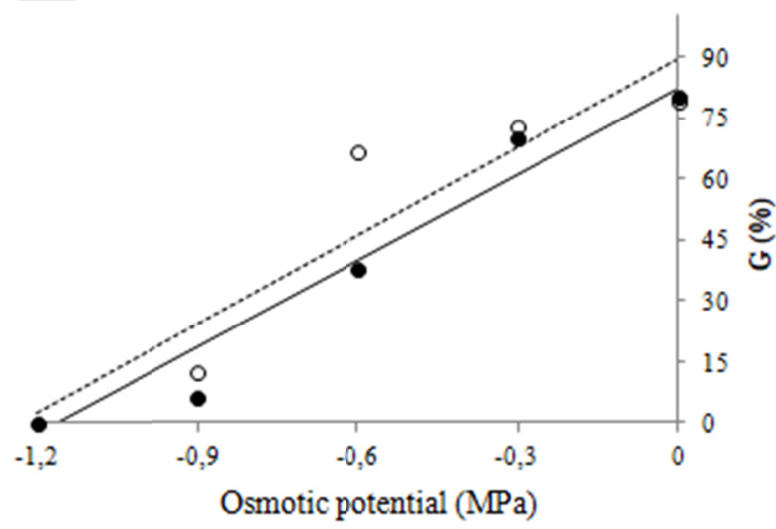

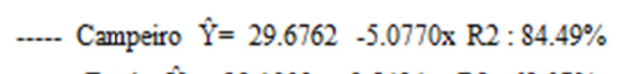

Esteio $\hat{Y}=23.1803-3.5494 \times$ R2 $: 62.07 \%$

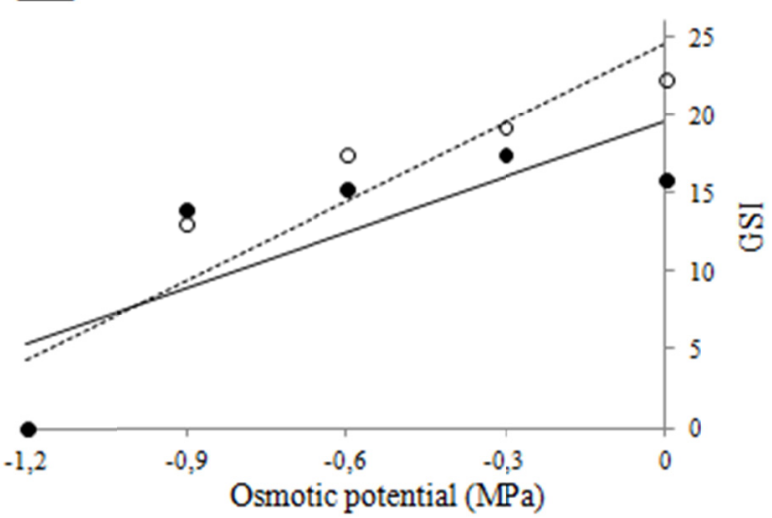

Figure 1. Germination (G-A), germination speed index (GSI-B) of seeds from two black bean cultivars subjected to different osmotic potential levels, in $\mathrm{NaCl}$ solutions

Reduced germination in seeds can be explained by an excess of salt, which interferes with the water potential of the soil, decreasing the potential gradient between soil and seed surface, inhibiting or restricting water withdrawal, which is vital for the activation or later maintenance of seed metabolism (Lopes \& Macedo, 2008). The same can be observed for the current research, since the seeds came into direct contact, in the moistened substrate, with saline solutions, thus reducing seed germination.

Machado Neto et al. (2006), working with water deficit induced by different osmotic agents in the germination and vigor of bean seeds from cultivar IAC-Carioca-80SH, and Coelho et al. (2010) with 'Pearl' beans, found that the stress caused by $\mathrm{NaCl}$ reduced seed germination, corroborating with the results of the present study.

The GSI of the seeds (Figure 1B) also presented linear behavior. For both studied cultivars, higher salinity caused significant decreases in the germination speed of the bean seeds, and, then again, cultivar Esteio showed a higher sensitivity as the potential of the osmotic solutions dropped, except for values inferior to $-0.9 \mathrm{MPa}$.

This behavior may be linked to a difficulty in water absorption by the seeds, affecting cell division and expansion processes, directly interfering with embryonic growth and development (Klafke et al., 2012). Excessively low water potentials, especially in the beginning of the imbibition process, negatively affect water absorption by seeds, which may hinder the sequence of events related to their germination process (Moterle et al., 2006). According to Andréo-Souza et al. (2010), germination speed is the first parameter affected by reduced water availability caused by the presence of salts, when in excess and available in substrates where the seeds are.

Analyzing the effect of cultivars within each osmotic potential (Table 1), it is possible to see that in potentials of 0.0 and $-0.3 \mathrm{MPa}$, the germination percentages of the cultivars did not differ and were higher than $70 \%$, meeting the minimum germination standard recommended for the commercialization of basic bean seeds in Brazil (Brasil, 2013). However, for osmotic potentials of -0.6 and $-0.9 \mathrm{MPa}$, cultivar Esteio proved to be more sensitive to salinity, and at $-1.2 \mathrm{MPa}$, the germination of both cultivars was null (Table 1). Salinity response may vary by species and cultivars within the same species (Prisco \& Gomes Filho, 2010). 
Table 1. Germination (G), germination speed index (GSI) of black bean seeds by cultivar and osmotic potential levels, in $\mathrm{NaCl}$ solutions

\begin{tabular}{|c|c|c|c|c|c|}
\hline \multirow{2}{*}{ Cultivars } & \multicolumn{5}{|c|}{ Osmotic potentials (MPa) } \\
\hline & 0.0 & -0.3 & -0.6 & -0.9 & -1.2 \\
\hline \multicolumn{6}{|l|}{$G(\%)$} \\
\hline Campeiro & $79.00 \mathrm{~A}$ & $72.00 \mathrm{~A}$ & $67.00 \mathrm{~A}$ & $12.00 \mathrm{~A}$ & $0.00 \mathrm{~A}$ \\
\hline Esteio & $80.00 \mathrm{~A}$ & $71.00 \mathrm{~A}$ & $38.00 \mathrm{~B}$ & $6.00 \mathrm{~B}$ & $0.00 \mathrm{~A}$ \\
\hline $\mathrm{CV}(\%)$ & 9.09 & & & & \\
\hline \multicolumn{6}{|l|}{$G S I$} \\
\hline Campeiro & $22.30 \mathrm{~A}$ & $19.30 \mathrm{~A}$ & $17.50 \mathrm{~A}$ & $13.10 \mathrm{~A}$ & $0.00 \mathrm{~A}$ \\
\hline Esteio & $16.00 \mathrm{~B}$ & $17.50 \mathrm{~A}$ & $15.30 \mathrm{~A}$ & $13.90 \mathrm{~A}$ & $0.00 \mathrm{~A}$ \\
\hline $\mathrm{CV}(\%)$ & & & 16.69 & & \\
\hline
\end{tabular}

Note. Means followed by the same letter in the column do not differ from each other by Tukey's test, at a $5 \%$ significance.

Comparing cultivars as to use of different osmotic potentials, it can be observed, for variable 'GSI' (Table 1), that in environments with no saline stress $(0.0 \mathrm{MPa})$, there was significant statistical difference between cultivars, since the highest indexes were obtained in seeds from cultivar Campeiro. However, in osmotic potentials of -0.3 , -0.6 and $-0.9 \mathrm{MPa}$, the cultivars did not differ from each other, and at the highest concentration $(-1.20)$, GSI values were null for the two cultivars. This may have occurred due to salinity reducing the osmotic potential of the solution, thus delaying seed germination for both assessed cultivars (Lopes \& Macedo, 2008).

According to Coelho et al. (2010), the vigor of bean seeds reduces more pronouncedly when exposed to solutions with osmotic potentials lower than $-0.9 \mathrm{MPa}$.

The first germination count (Figure 2), which expresses seed vigor, presented linear behavior inversely proportional to the increase in $\mathrm{NaCl}$ concentrations. As the osmotic potential becomes more negative, meaning higher presence of $\mathrm{NaCl}$, the number of normal seedlings drops.

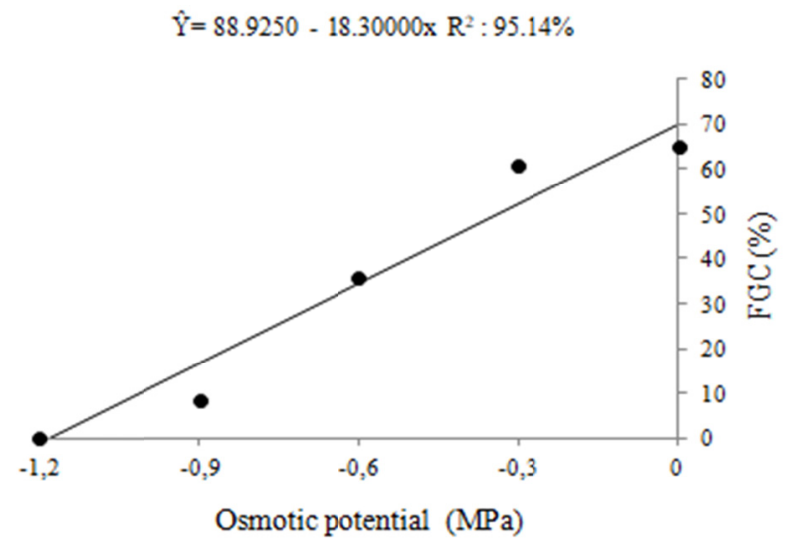

Figure 2. First germination count (FGC) of black bean seeds subjected to different osmotic potential levels, in $\mathrm{NaCl}$ solutions

To Abud et al. (2013), the first germination count is a simple vigor test run simultaneously with the germination test and is based on the assumption that more vigorous seeds germinate faster.

Comparing cultivars, it is possible to notice, for variables 'First germination count', 'fresh mass' and 'dry mass' (Table 2), that the seeds from cultivar Campeiro stood out as the most vigorous ones. These results can be attributed to the genetic constitution of the cultivar itself. 
Table 2. First germination count (FGC), fresh mass (FM) and dry mass (DM) of seedlings from black bean seeds by cultivar and osmotic potential levels, in $\mathrm{NaCl}$ solutions

\begin{tabular}{llll}
\hline \multirow{2}{*}{ Cultivars } & \multicolumn{3}{c}{ Variables } \\
\cline { 2 - 4 } & FGC $(\%)$ & FM $(\mathrm{g})$ & DM $(\mathrm{g})$ \\
\hline Campeiro & $37.00 \mathrm{~A}$ & $12.30 \mathrm{~A}$ & $3.40 \mathrm{~A}$ \\
Esteio & $31.00 \mathrm{~B}$ & $10.60 \mathrm{~B}$ & $2.80 \mathrm{~B}$ \\
\hline CV $(\%)$ & 22.50 & 22.12 & 24.17 \\
\hline
\end{tabular}

Note. Means followed by the same letter in the column do not differ from each other by Tukey's test, at a 5\% significance.

The behavior of variables 'fresh mass' and 'dry mass' of seedlings as a function of osmotic potential levels, in $\mathrm{NaCl}$ solutions, are illustrated in Figure 3. The results fit into a regression equation of linear behavior, with reduced accumulation of fresh mas and dry mass of seedlings being proportional to decreases in osmotic potential.
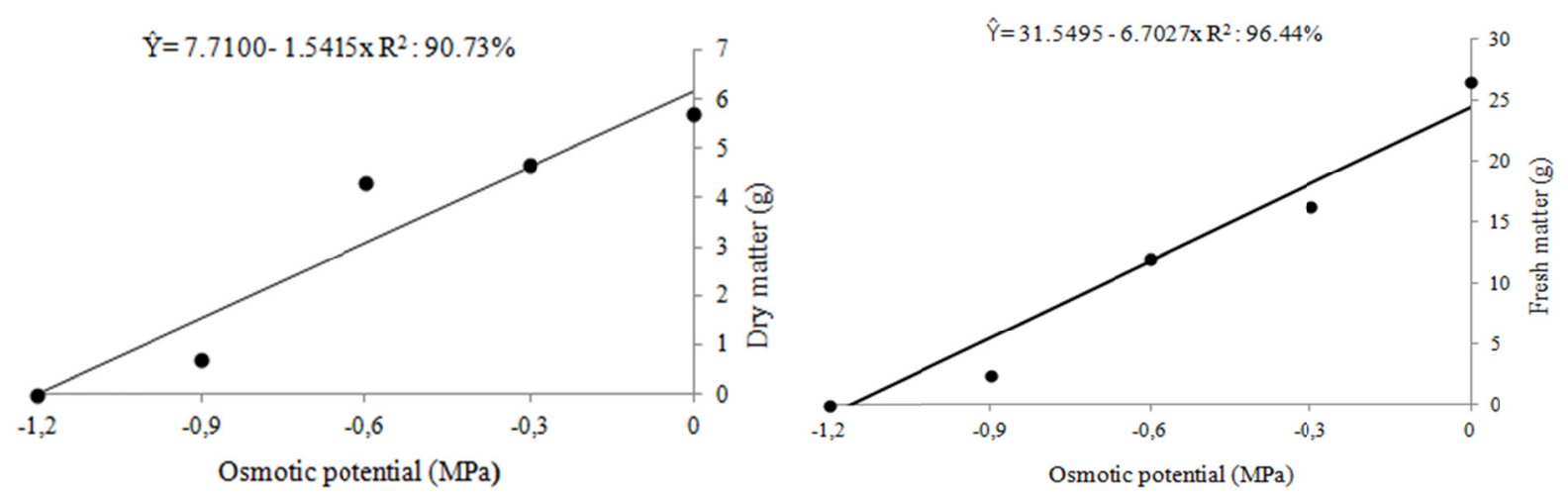

Figure 3. Fresh matter (FM-A) and dry matter (DM-B) of seedlings from black bean seeds subjected to different osmotic potential levels, in $\mathrm{NaCl}$ solutions

High salinity delays the embryo's metabolism and transport of reserves, which affects seedling development and, consequently, fresh and dry matter accumulation (Bewley \& Black, 1994). According to Lopes et al. (2014), growth reduction is one of the most evident factors of saline stress in plants.

This reduction in growth is related to low water availability and high salinity levels in the substrate. Moreover, a high saline level leads to changes in the plant's capacity to absorb, transport and utilize the ions necessary for its growth, for reducing metabolic assimilation rates, for the activity of enzymes responsible for respiration and photosynthesis, thus restricting the sourcing of energy for the growth and differentiation of cells in tissues, reducing the elongation of the embryonic axis and the production of dry mass (Nobre et al., 2010).

In this sense, Matias et al. (2015) stress that when there are restrictions in water availability, water absorption by the seed slows down. The seed starts germination, and the small amount of water for it to continue can impair the growth of the embryonic axis, which justifies a lower development and dry matter accumulation in seedlings.

\section{Conclusions}

The germination and vigor of seeds from the black bean cultivars were negatively affected under saline stress caused by $\mathrm{NaCl}$ solution with osmotic potential inferior to $-0.6 \mathrm{MPa}$.

The seeds from the cultivars revealed differentiated behavior as to the saline stress conditions, and cultivar Campeiro proved to be more tolerant to saline stress during the germination process and seedling formation.

\section{Acknolwedgements}

To the Coordination for the Improvement of Higher Education Personnel (CAPES), to Minas Gerais Research Foundation (FAPEMIG) and to the State University of Montes Claro (UNIMONTES). 


\section{References}

Abud, H. F., Araujo, E. F., Araujo, R. F., Araujo, A. V., \& Pinto, C. M. F. (2013). Qualidade fisiológica de sementes das pimentas malagueta e biquinho durante a ontogênese. Pesquisa Agropecuária Brasileira, 48(12), 1546-1553. https://doi.org/10.1590/S0100-204X2013001200003

Andreo-Souz, Y., Pereira, A. L., Silva, F. F. S. da, Reis-Ribeiro, R. C., Evangelista, M. R. V., Castro, R. D. de, \& Dantas, B. F. (2010). Efeito da salinidade na germinação de sementes e no crescimento inicial de mudas de pinhão-manso. Revista Brasileira de Sementes, 32(2), 83-92. https://doi.org/10.1590/S0101-31222010000 200010

Bewley, J. D., \& Black, M. (1994). Seeds: Physiology of development and germination (2rd ed.). New York, NY: Springer. https://doi.org/10.1007/978-1-4899-1002-8

Brasil, Ministério da Agricultura, Pecuária e Abastecimento, Secretaria de Defesa Agropecuária. (2009). Regras para análise de sementes. Brasília: MAPA.

Brasil, Ministério da Agricultura, Pecuária e Abastecimento. (2013). Estabelece os padrões de identidade e qualidade para produção e comercialização de sementes de feijão, disposto em anexo (Instrução Normativa $n^{\circ}$ 45, de 17 de Setembro de 2013, Seção 1, no 183, pp. 13-14). Diário Oficial da República Federativa do Brasil, Poder executivo, Brasília, DF,

Coelho, D. L. M., Agostini, E. A. T. de, Gualberto, L. M., Machado Neto, N. B., \& Custódio, C. C. (2010). Estresse hídrico com diferentes osmóticos em sementes de feijão e expressão diferencial de proteínas durante a germinação. Acta Scientiarum Agronomy, 32(3), 491-499. https://doi.org/10.4025/actasciagron. v32i3.4694

Figliolia, M. B., Oliveira, E. C., \& Piña Rodrigues, F. C. M. (1993). Análise de sementes. In I. B. Aguiar, F. C. M. Piña Rodrigues, \& M. B. Figliolia (Eds.), Sementes florestais tropicais (pp. 137-174). ABRATES, Brasília.

Klafke, A. V., Lopes, R. R., \& Franke, L. B. (2012). Desempenho de sementes nuas e revestidas de azevém anual em condições de estresse salino. Revista. Brasileira de Zootecnia, 41(5), 1093-1099. https://doi.org/ 10.1590/S1516-35982012000500003

Lopes, J. C., \& Macedo, C. M. P. (2008). Germinação de sementes de sob influência do teor de substrato e estresse salino. Revista Brasileira de Sementes, 30(3), 79-85. https://doi.org/10.1590/S0101-31222008000 300011

Lopes, K. P., Nascimento, M. G. R., Barbosa, R. C. A., \& Costa, C. C. (2014). Salinidade na qualidade fisiológica em sementes de Brassicas oleracea L. var. itálica. Semina: Ciências. Agrárias, 35(5), 2251-2260. https://doi.org/10.5433/1679-0359.2014v35n5p2251

Machado Neto, N. B., Custódio, C. C., Costa, P. R., \& Doná, F. L. (2006). Deficiência hídrica induzida por diferentes agentes osmóticos na germinação e vigor de sementes de feijão. Revista Brasileira de Sementes, 28(2), 142-8. https://doi.org/10.1590/S0101-31222006000100020

Maguire, J. D. (1962). Speed of germination aid in selection and evaluation for seedling emergence and vigor. Crop Science, 2(2), 176-77. https://doi.org/10.2135/cropsci1962.0011183X000200020033x

Matias, J. R., Santos, S. T. C. F., Oliveira, G. M., Aragão, C. A., \& Dantas, B. F. (2015). Germinação de sementes de pepino cv. caipira em condições de estresse. Revista Sodebras, 10(110), 33-39.

Moterle, L. M., Lopes, P. C., Braccini, A. L., \& Scapim, C. A. (2006). Germinação de sementes e crescimento de plântulas de cultivares de milho-pipoca submetidas as estresse hídrico e salino. Revista Brasileira de Sementes, 28(3), 169-176. https://doi.org/10.1590/S0101-31222006000300024

Nobre, R. G., Gheyi, H. R., Correia, K. G., Soares, F. A. L., \& Andrade, L. O. (2010). Crescimento e floração do girassol sob estresse salino e adubação nitrogenada. Revista Ciência Agronômica, 41(3), 358-365. https://doi.org/10.1590/S1806-66902010000300006

Prisco, J. T., \& Gomes-Filho, E. (2010). Fisiologia e bioquímica do estresse salino em plantas. In H. R. Gheyi, N. da. S. Dias, \& C. F de Lacerda (Eds.), Manejo da salinidade na agricultura: Estudos básicos e aplicados (pp. 147-164). Fortaleza: INCTSal.

Santos, P. R., Ruiz, H. A., Neves, J. C. L., Freire, M. B. G., \& Freire, F. J. (2009). Acúmulo de cátions em dois cultivares de feijoeiro crescidos em soluções salinas. Revista Ceres, 56(5), 666-678. 
Scheeren, B. R., Peske, S. T., Schuch, L. O. B., \& Barros, A. C. A. (2010). Qualidade fisiológica e produtividade de sementes de soja. Revista Brasileira de Sementes, 32(3), 35-41. https://doi.org/10.1590/S0101-31222 010000300004

Villela, F. A., Doni-Filho, L., \& Sequeira, E. L. (1991). Tabela de potencial osmótico em função da concentração de polietileno glicol 6000 e da temperatura. Pesquisa Agropecuária Brasileira, 26(11), 1957-1968.

Wendt, L., Malavasi, M. M., Dranski, J. A. L., Malavasi, U. C., \& Gomes Junior, F. G. (2017). Relação entre testes de vigor com a emergência a campo em sementes de soja. Revista Brasileira de Ciências Agrárias, 12(2), 166-171. https://doi.org/10.5039/agraria.v12i2a5435

\section{Copyrights}

Copyright for this article is retained by the author(s), with first publication rights granted to the journal.

This is an open-access article distributed under the terms and conditions of the Creative Commons Attribution license (http://creativecommons.org/licenses/by/4.0/). 